\title{
Alteration in the Chemical Composition of Immortelle, Silver Fir and Prickly Juniper Essential Oils Induced by Light
}

\author{
Ilijana Odak, ${ }^{1, \star}$ Irena Škorić, ${ }^{2}$ Daria Grbavac, ${ }^{1}$ Ana Ratković ${ }^{2}$ and Ivana Šagud ${ }^{2}$ \\ ${ }^{1}$ Department of Chemistry, Faculty of Science and Education, University of Mostar, Matice hrvatske bb, \\ 88000 Mostar, Bosnia and Herzegovina. \\ ${ }^{2}$ Department of Organic Chemistry, Faculty of Chemical Engineering and Technology, University of Zagreb, \\ Marulićev trg 19, 10000 Zagreb, Croatia \\ * Corresponding author: E-mail: ilijana.odak@fpmoz.sum.ba \\ Tel: +38736445478, Fax:+38736355458
}

Received: 03-12-2019

\begin{abstract}
The objective of this study was to evaluate impact of light and available oxygen on the chemical composition of three selected essential oils. Aliquots of immortelle (Helichrysum italicum), silver fir (Abies alba) and prickly juniper (Juniperus oxycedrus) essential oils were exposed to UV-A irradiation in the presence of atmospheric oxygen as well as in the presence of inert gas. The compositions of fresh and irradiated samples were studied by GC-MS. Each oil showed an individual response to the applied conditions. In immortelle oil, dominant process was phototransformation of $\gamma$-curcumene to italicene, isoitalicene and $\alpha$-curcumene. Since $\gamma$-curcumene is one of the major components of immortelle essential oil, exposure of this oil to light can cause significant changes in primary composition and thus quality. In silver fir and prickly juniper oil irradiation caused only slight changes among sesquiterpenes that are present as minor components. Both oils were found to be photostabile and insensitive to the presence of atmospheric oxygen.
\end{abstract}

Keywords: Essential oil; photostability; phototransformation; cycloaddition; dehydrogenation; UV-Vis promoted deterioration

\section{Introduction}

Phytochemicals have long history of usage in nutrition, medicine and cosmetics due to the wide range of beneficial properties they possess. Nowadays, the interest in phytochemicals is continuously growing, whether for healthy food, natural pharmaceuticals or personal care and household products. This can be attributed to the consumer's increased awareness regarding the "green" products and an overall greater health consciousness. An important class of natural products in food and cosmetics industries as well as in folk medicine are essential oils. As defined by the International Organization for Standardization (ISO 9235, 2013) essential oil is a "product obtained from raw plant material by steam distillation, by mechanical processes from the epicarp of citrus fruits, or by dry distillation, after separation of the aqueous phase, if any, by physical processes." Usages of essential oils overcame the traditional medicinal practices and nowadays they are widely applied in the cosmetics, pharmaceutical and food industries. ${ }^{1-3}$ Such various areas of essential oils application result from the differences in their chemical composition which range from very simple to highly complex, containing more than 100 constituents. Specific features of essential oils, such as antioxidant properties or odor, do not depend only on the major components but also on the synergism between these components and the structure and properties of each. Terpenes well known for their pharmacological properties, also serve as lead compounds in synthesis of derivatives that might possess improved biological activity. ${ }^{4,5}$

Components of essential oils including terpenes, esters, aromatic hydrocarbons and phenols, may undergo changes when exposed to air, heat or light. They can be transformed into one another by oxidation, isomerization, cyclization or dehydrogenation or may be transformed into other products by the same reactions as well as by polymerization and degradation. ${ }^{6}$ Changes in the composition of the starting material can lead to the decline in qual- 
ity and its biological properties ${ }^{7}$ and even lead to compounds that can cause harm to the user. ${ }^{8,9}$ In order to develop efficient use of essential oils in various areas of applications, it is necessary to carry out research regarding their properties, chemical composition as well as photostability or changes in the composition during storage and usage. Ultraviolet and visible light is found to cause faster compositional changes through the reactions of oxidation, photocycloaddition and isomerization. Mieting et al. ${ }^{10}$ found photoanethole in stored essential oil from anis, as a result of photocycloaddition between anethole and anisaldehyde. In sweet fennel oil, trans-anethole isomerizes to cis-anethole and oxidizes to anisaldehyde under the influence of light. ${ }^{11}$ Turek and Stintzing ${ }^{12,13}$ found degradation of some monoterpenes in rosemary oil under the influence of light while thyme oil does not show significant changes when exposed to daylight.

In this paper, three commercially available essential oils from Bosnia and Herzegovina (B\&H) were studied in order to determine their photostability. Territory of $\mathrm{B} \& \mathrm{H}$ is characterized by high floristic diversity. A large number of medicinal and aromatic plant species are native to $\mathrm{B} \& \mathrm{H}$ and represent an important economic resource. $\mathrm{B} \& \mathrm{H}$ is covered with coniferous woods, which has resulted in widespread usage of products derived from this species. Essential oils from Abies alba is industrially one of the most important in B\&H. Silver fir oil is used commercially in cosmetic and fragrance industries as well as household products. ${ }^{14}$ Another important conifer is Juniperus oxycedrus (prickly juniper) and its essential oil which is used in many pharmaceutical skin preparations and veterinary medicine. One of the most cultivated aromatic plants in Herzegovina is Helichrysum italicum subsp. italicum (immortelle) due to the economic value of its essential oil. It is a highly valued oil with a complex chemical composition, used in perfume and cosmetics industry. ${ }^{15}$

The influence of light on the chemical changes of selected essential oils has been studied in the conditions that cause accelerated changes induced by light. Irradiated samples were analyzed by GC-MS and compared to the fresh ones in order to evaluate potential changes in chemical composition.

\section{Experimental}

\section{1. Plant Material and Chemicals}

Fresh samples of immortelle, silver fir and prickly juniper essential oils were obtained from distillery plant Roing Ltd. (B\&H, http://www.essential-oils.ba/). Oils were obtained by steam distillation of the corresponding plants, all harvested in Herzegovina region in 2017, and dried over anhydrous sodium sulphate. Pentane, DMSO and petroleum ether were obtained from Sigma-Aldrich (St. Louis, MO, USA). Silica gel (Fluka $0.063-0.2 \mathrm{~mm}$ ) was used for chromatographic purifications.

\section{2. Photochemical Testing}

Essential oil samples were prepared as follows: aliquots of $1 \mathrm{~mL}$ were filled in $2 \mathrm{~mL}$ clear glass vials and closed with sealing plugs with the air left in the headspace (conditions A). The second set of samples was prepared in the same way but flushed with pure nitrogen (conditions B). The sealed vials were irradiated for 48 hours (or more) at $25^{\circ} \mathrm{C}$ in a Luzchem CCP-ICH2 photoreactor equipped with 16 lamps of the $366 \mathrm{~nm}$ wavelength. After irradiation, oil samples were analyzed using GC-MS system.

\section{3. Gas Chromatography-Mass Spectrometry Analysis}

The analysis of the oils was carried out using Shimadzu GC-MS QP2010 system equipped with an AOC-20i autosampler, using fused silica capillary column Inert Cap (5\% diphenyl - 95\% dimethylpolysiloxane, $30 \mathrm{~m} \times 0.25$ $\mathrm{mm}$ i.d., film thickness $0.25 \mu \mathrm{m}$ ). $1.0 \mu \mathrm{L}$ of solution diluted 1:500 $v / v$ in pentane was injected in splitless mode with helium as carrier gas. For immortelle essential oil, the operating conditions were as follows: injection temperature 250 ${ }^{\circ} \mathrm{C}$; helium flow rate, $1.15 \mathrm{~mL} / \mathrm{min}$; oven temperature program: $60^{\circ} \mathrm{C}(1.5 \mathrm{~min}), 60-120^{\circ} \mathrm{C}\left(5^{\circ} \mathrm{C} / \mathrm{min}\right), 120-240{ }^{\circ} \mathrm{C}$ $\left(4{ }^{\circ} \mathrm{C} \mathrm{min}\right), 240^{\circ} \mathrm{C}(2 \mathrm{~min})$. MS (EI) conditions: ion source temperature: $250^{\circ} \mathrm{C}$, interface temperature: $250{ }^{\circ} \mathrm{C}$, ionization voltage: $70 \mathrm{eV}$, mass range: $m / z 40-400 \mathrm{u}$, scan time: $0.5 \mathrm{sec}$. For silver fir oil, the operating conditions were as follows: injection temperature $260^{\circ} \mathrm{C}$; helium flow rate, $1.11 \mathrm{~mL} / \mathrm{min}$; oven temperature program: $50{ }^{\circ} \mathrm{C}(5 \mathrm{~min})$, $50-260{ }^{\circ} \mathrm{C}\left(3{ }^{\circ} \mathrm{C} / \mathrm{min}\right), 260^{\circ} \mathrm{C}(15 \mathrm{~min})$. MS (EI) conditions: ion source temperature: $200^{\circ} \mathrm{C}$, interface temperature: $280{ }^{\circ} \mathrm{C}$, ionization voltage: $70 \mathrm{eV}$, mass range: $\mathrm{m} / \mathrm{z}$ 40-400 u, scan time: $0.5 \mathrm{sec}$. The operating conditions for prickly juniper oil were as follows: injection temperature $250{ }^{\circ} \mathrm{C}$; helium flow rate, $1.06 \mathrm{~mL} / \mathrm{min}$; oven temperature program: $60^{\circ} \mathrm{C}(2 \mathrm{~min}), 60-200{ }^{\circ} \mathrm{C}\left(3^{\circ} \mathrm{C} / \mathrm{min}\right), 200^{\circ} \mathrm{C}(10$ min). MS (EI) conditions: ion source temperature: $200^{\circ} \mathrm{C}$, interface temperature: $250{ }^{\circ} \mathrm{C}$, ionization voltage: $70 \mathrm{eV}$, mass range: $m / z \quad 40-400 \mathrm{u}$; scan time: $0.5 \mathrm{sec}$. GCMSolution 2.5 (Shimadzu) was used to handle data. GC-MS analyses were performed in triplicate and the results are represented as mean values.

Identification of oil components was based on (a) retention indices on a non-polar column relative to a homologous series of $n$-alkanes $\left(\mathrm{C}_{8}-\mathrm{C}_{40}\right)$; (b) on the comparison of their mass spectra and retention indices with the Wiley 7 and NIST spectra libraries and with those reported in the literature. ${ }^{16-19}$

\section{4. Fractionation and Irradiation of Immortelle Essential Oil}

Sample of immortelle essential oil was subjected to vacuum distillation in order to remove $\alpha$-pinene and oth- 
er monoterpenes of lower boiling points. The residue was distributed by liquid-liquid extraction in DMSO - hexane system. After removal of hexane on rotary evaporator, nonpolar fraction was subjected to column chromatography on silica gel using petroleum ether as eluent, yielding a fraction with $80 \%$ of $\gamma$-curcumene. Two sets of samples were prepared, one with the air in a headspace of the vial and one flushed with nitrogen. Samples were irradiated in the photoreactor at $366 \mathrm{~nm}$ during 24 hours and analysed by GC-MS as described in part 2.3. for immortelle oil.

\section{Results and Discussion}

The influence of the light was assessed by brief irradiation in the photochemical reactor at a wavelength of $366 \mathrm{~nm}$ in order to imitate UV-A fraction of sunlight. Samples of fresh oils were kept in photoreactor under air (sample A) and under nitrogen (sample B) for 48 hours or longer. Table 1 shows compounds from particular oil whose percentage has changed during irradiation, while complete tables with full chemical composition of each freshly distilled oil can be found in Appendix. Changes higher than 0.2 in relative peak area were considered relevant.

\section{1. Immortelle Oil}

Essential oil of immortelle contained 70 components (Table A.1). $\alpha$-Pinene (28.5\%), $\gamma$-curcumene (9.8\%), $\beta$-selinene $(6.3 \%)$ and italicene $(5.0 \%)$ were the major components. Stability of immortelle essential oil was studied earlier by us under realistic storage conditions. ${ }^{20}$ The samples were left during a period of 12 months in the dark and daylight in the presence and absence of oxygen. The only significant change was a decrease in $\gamma$-curcumene percentage. Test in the photoreactor confirmed photochemical transformations that occurred during realistic storage conditions. Irradiation causes the transformation of $\gamma$-curcumene mostly to italicene and isoitalicene as a result of $[2+2]$-photocycloaddition and to the $\alpha$-curcumene via dehydrogenation/aromatization (Scheme 1, Table 1). Dehydrogenation to $\alpha$-curcumene is more favored when the oxygen is present in the headspace. Changes induced by light are more pronounced when the oil is flushed with inert gas rather then left in the air atmosphere. Since UV and Vis light accelerate autoxidation ${ }^{21}$ and polymerization processes, absence of oxygen allows photochemical transformations, such as cyclization, to take place to a greater extent.

To confirm this particular transformation, the fraction from the immortelle oil with the $\gamma$-curcumene as a major component was isolated by distillation, extraction

Table 1. Changes in GC-MS relative peak area of characteristic compounds during exposure of essential oils to various conditions

\begin{tabular}{lcccc}
\hline Compound & RI $^{\mathrm{a}}$ & \% Fresh & \multicolumn{2}{c}{ Changes in relative peak area } \\
\hline Immortelle oil & & & $\mathrm{A}^{\mathrm{b}}$ & $\mathrm{B}^{\mathrm{b}}$ \\
Isoitalicene & 1376 & 0.7 & +0.3 & +1.0 \\
Italicene & 1405 & 5.0 & +2.4 & +2.7 \\
$\gamma$-Curcumene & 1477 & 9.8 & -3.3 & -3.7 \\
$\alpha$-Curcumene & 1482 & 2.7 & +0.6 & +0.2 \\
\hline Silver fir oil & & & $\mathbf{A}^{\mathrm{c}}$ & $\mathbf{B}^{\mathrm{c}}$ \\
Caryophyllene & 1413 & 2.7 & -0.5 & -0.3 \\
Himachala-2,4-diene & 1418 & 1.0 & -0.5 & -0.5 \\
\hline Prickly juniper oil & & & $\mathbf{A}^{\mathrm{b}}$ & $\mathbf{B}^{\mathrm{b}}$ \\
Bourbonene & 1379 & $\operatorname{tr}$ & +0.3 & +0.4 \\
Germacrene D & 1476 & 1.9 & -0.3 & -0.4 \\
\hline
\end{tabular}

${ }^{a}$ RI: retention indices. ${ }^{b}$ Storage condition A: 48 h, air; B: 48 h, nitrogen. ${ }^{c}$ Storage condition A: 146 h, air; B: $146 \mathrm{~h}$, nitrogen.
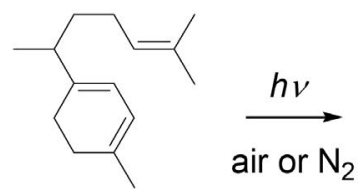

$\gamma$-curcumene

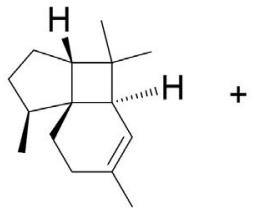

italicene

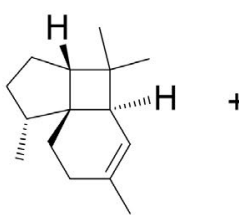

isoitalicene

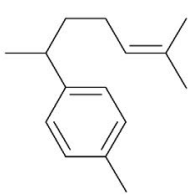

$\alpha$-curcumene

Scheme 1. Photochemical transformations of $\gamma$-curcumene 
and column chromatography. The GC-MS analysis of the irradiated fraction revealed that the $\gamma$-curcumene completely disappears and is transformed to the above-mentioned products. Among two cycloaddition products, italicene is formed in greater amount than isoitalicene because the conformation of $\gamma$-curcumene that leads to italicene by suprafacial $[2+2]$-photocycloaddition is more favorable than the conformation that leads to isoitalicene by the same suprafacial $[2+2]$-photocycloaddition.

\section{2. Silver Fir Oil}

In fresh oil a total of 67 compounds was identified, representing $98.3 \%$ of the chemical composition (Table A.2). The major compounds present in silver fir oil were $\beta$-pinene (24.1\%), limonene (23.6\%), $\alpha$-pinene (17.8\%), camphene $(9.1 \%)$ and bornyl acetate $(9.0 \%)$. After 48 hours of irradiation in the atmosphere of air or nitrogen (samples A and B) the oil kept its original composition. Prolonging irradiation to 146 hours caused decline in caryophyllene and himachala-2,4-diene amount (Table 1). A few new peaks appeared among sesquiterpenes which were difficult to identify due to small amount. Oxygen presence or absence does not play any role in photochemical stability, so the observed changes cannot be attributed to oxidations.

\section{3. Prickly Juniper Oil}

Analysis of fresh prickly juniper oil identified 46 compounds, representing $98.2 \%$ of the total oil (Table A.3). The predominant components in prickly juniper were $\beta$-myrcene (48.0\%), $\alpha$-pinene $(24.7 \%)$ and limonene (9.0\%). After 48 hours of irradiation the only noticeable change was a slight decrease of germacrene $\mathrm{D}$, while other compounds were retained in their initial shares. This ten-membered ring with two double bonds is photochemically reactive as demonstrated by Bulow et al. ${ }^{22}$ in photochemically induced rearrangement experiments with isolated germacrene D. Bourbonene is one of the main photoproducts, and it was detected in chromatogram with increased amount after irradiation (Table 1).

\section{Conclusion}

Photostability investigation on the three selected essential oils demonstrated individual character of these oils in response to irradiation. $\gamma$-Curcumene is rarely found in natural products in larger proportions due to its reactivity. Its relatively high content in immortelle oil makes this oil special in its chemical composition and contributes significantly to its odor and biological activity. ${ }^{23}$ It is showed that this reactive sesquiterpene is sensitive to light and undergoes photochemical transformation to another interesting structure, that of italicenes that contain a rare four-membered ring. Thus, if it is desired to maintain an original amount of $\gamma$-curcumene, it is necessary to keep this oil in the dark. Silver fir oil is photochemically stabile regardless of oxygen availability. It is not necessary to store the oil in the dark and under the inert gas. Prickly juniper oil also showed good photostability, especially among monoterpenes that preserved their shares. The amount of change during exposure to UV light was very low under both sets of conditions.

\section{Acknowledgement}

This work was supported by Federal Ministry of Education and Science, Bosnia and Herzegovina [Grant No.05-39-3831-1/15].

\section{Appendix}

Chemical composition of the freshly distilled immortelle, silver fir and prickly juniper essential oils can be found in Appendix.

\section{References}

1. V. R. Preedy, Essential Oils in Food Preservation, Flavor and Safety, 1st Ed, Academic Press, Amsterdam, 2016.

2. R. G. Berger, Flavours and Fragrances: Chemistry, Bioprocessing and Sustainability, Springer-Verlag, Berlin Heidelberg, 2007. DOI:10.1007/978-3-540-49339-6

3. J. S. Raut, S. M. Karuppayil, Ind. Crops Prod. 2014, 62, 250 264. DOI:10.1016/j.indcrop.2014.05.055

4. J. Lazarević, A. Kolarević, G. Stojanović, A. Smelčerović, P. Ciuffreda, E. Santaniello, Acta Chim. Slov. 2018, 65, 801-810. DOI:10.17344/acsi.2018.4380

5. J. Lazarević, A. Kolarević, A. Đorđević, G. Stojanović, A. Smelčerović, P. Ciuffreda, E. Santaniello, Acta Chim. Slov. 2017, 64, 603-612. DOI:10.17344/acsi.2017.3356

6. C. Turek, F. C. Stintzing, Compr. Rev. Food Sci. Food Saf. 2013, 12, 40-53. DOI:10.1111/1541-4337.12006

7. K. H. Kubeczka, in: R. Carle (Ed.): Atherische Ole - Anspruch und Wirklichkeit, Wissenschaftliche Verlagsgesellschaft, Stuttgart, 1993, 85-102.

8. M. Skold, L. Hagvall, A. T. Karlberg, Contact Derm. 2008, 58, 9-14. DOI:10.1111/j.1600-0536.2007.01262.x

9. J. Brared-Christensson, M. Matura, B. Gruvberger, M. Bruze, A. T. Karlberg, Contact Derm. 2010, 62, 32-41. DOI:10.1111/j.1600-0536.2009.01657.x

10. H. Miething, V. Seger, R. Hansel, Phytother. Res. 1990, 4, $121-$ 123. DOI:10.1002/ptr.2650040311

11. T. A. Misharina, A. N. Polshkov, Appl. Biochem. Microbiol. 2005, 41, 693-702. DOI:10.1007/s10438-005-0111-8

12. C. Turek, F. C. Stintzing, J. Food Sci. 2011, 76, 1365-1375. DOI:10.1111/j.1750-3841.2011.02416.x 
13. C. Turek, F. C. Stintzing, Food Res. Int. 2012, 46, 341-353. DOI:10.1016/j.foodres.2011.12.028

14. A. Wajs-Bonikowska, M. Sienkiewicz, A. Stobiecka, A. Maciag, L. Szoka, E. Karna, Chem. Biodivers. 2015, 12, 407-418. DOI:10.1002/cbdv.201400167

15. D. A. Viegas, A. Palmeira-de-Oliveira, L. Salgueiro, J. Martinez-de-Oliveira, R. Palmeira-de-Oliveira, J. Etnopharm. 2014, 151, 64-65.

16. R. P. Adams, Identification of Essential oil Components by Gas Chromatography/Mass Spetroscopy. 4th ed., Allured Publ. Corp, Carol Stream, IL, 2007.

17. V. I. Babushok, P. J. Linstrom, I. G. Zenkevich, J. Phys. Chem. Ref. Data 2011, 40, 043101. DOI:10.1063/1.3653552

18. NIST Chemistry WebBook. https://webbook.nist.gov/chemistry/ (20 December 2018)
19. A. Bianchini, P. Tomi, J. Costa, A.F. Bernardini, Flavour Fragrance J. 2001, 16, 30-34.

DOI:10.1002/1099-1026(200101/02)16:1<30::AID-FFJ941> 3.0.CO;2-F

20. I. Odak, T. Lukić, S. Talić, J. Essent. Oil Bear. Pl. 2018, 21, 614-622. DOI:10.1080/0972060X.2018.1489309

21. E. Choe, D. B. Min, Compr. Rev. Food Sci. Food Saf. 2006, 5, 169-186. DOI:10.1111/j.1541-4337.2006.00009.x

22. N. Bullow, W. A. Konig, Phytochemistry. 2000, 55, 141-168. DOI:10.1016/S0031-9422(00)00266-1

23. A. Sala, M. Recio, R. M. Giner, S. Manez, H. Tournier, G. Schinella, J. L. Rios, J. Pharm. Pharmacol. 2002, 54, 365-371. DOI:10.1211/0022357021778600

\section{Povzetek}

Namen te študije je bil ugotoviti učinek svetlobe in kisika na kemijsko sestavo treh eteričnih olj. Alikvote olja iz laškega smilja (Helichrysum italicum), bele jelke (Abies alba) in vrste brina (Juniperus oxycedrus) smo izpostavili obsevanju $\mathrm{z}$ UV-A svetlobo v prisotnosti atmosferskega kisika in v prisotnosti inertnega plina. Sestavo svežih in obsevanih vzorcev smo raziskali z GC/MS. Vsako izmed olj je pokazalo drugačen odziv na uporabljene pogoje. Pri olju iz laškega smilja je bil glavni proces fototransformacija $\gamma$-kurkumena v italicen, izoitalicen in $\alpha$-kurkumen. Ker je $\gamma$-kurkumen ena izmed glavnih sestavin eteričnega olja laškega smilja, lahko izpostavljenost tega olja svetlobi povzroči bistvene spremembe $\mathrm{v}$ njegovi sestavi in s tem tudi kakovosti. Pri olju bele jelke in brina pa je obsevanje povzročilo zgolj majhne spremembe pri seskviterpenih, ki pa so prisotni samo v manjših deležih. Obe olji sta se torej izkazali kot fotostabilni in neobčutljivi na prisotnost atmosferskega kisika.

Except when otherwise noted, articles in this journal are published under the terms and conditions of the Creative Commons Attribution 4.0 International License 